\title{
RANCANG BANGUN SISTEM PENGIDENTIFIKASI TRAVEL BAG PADA KELOMPOK BIRO PERJALANAN UMROH/HAJI BERBASIS WEB
}

\author{
Timbo Faritcan Parlaungan Siallagan ${ }^{* 1}$, Dede wisnu ${ }^{\# 2}$
}

\author{
Program Studi Teknik Komputer dan Jaringan, STMIK Subang ${ }^{* 1}$ \\ Program Studi Teknik Komputer dan Jaringan, STMIK Subang ${ }^{\# 2}$ \\ E-mail : timbo.siallagan@yahoo.co.id ${ }^{* 1}$, dedewisnu@gmail.com \#2
}

\begin{abstract}
ABSTRAKSI
Perkembangan Teknologi Informasi salah satunya bergerak di bidang jasa Perjalanan Umrah. Salah satunya pencatatan yang dilakukan adalah proses pencatatan dan identifikasi terhadap kepemilikan tas peserta umrah atau haji. Pencatatan yang dilakukan secara manual atau diatas kertas akan menyulitkan proses identifikasi tas karena beresiko besar untuk rusak maupun hilang.

Sistem informasi berbasis web yang berjalan di jaringan computer diintegrasikan dengan perangkat keras mikrokontroler dapat dimanfatkan untuk pencatatan data dan identifikasi tas secara digital. Penggunaan system dengan metode digital akan mempermudah identifikasi tas. Yang akan menjadi lebih cepat dan data tersimpan secara aman.

Perancangan dan pembuatan system pengidentifikasian travel bag berbasis web menggunakan mikrokontroler adalah solusi untuk aplikasi pencatatan data dan identifikasi tas peserta dari biro perjalanan umroh atau haji. Dengan menggunakan system ini pihak biro perjalanan dan peserta akan merasa aman dan nyaman karena resiko tas tertukar sangat minim. Selain itu seluruh data tas dan pemiliknya tersimpan secara digital dan bisa diakses.
\end{abstract}

\section{Kata kunci : Arduino Uno, PHP, XAMMP, MYSQL, Scan RFID, Travel Bag}

\section{ABSTRACTION}

The development of Information Technology, one of which is engaged in Umrah Travel services. One of them is the process of recording and identifying the ownership of Umrah or Hajj participant bags. Recording done manually or on paper will make it difficult to identify the bag because it is at great risk for damage or loss.

Web-based information systems that run on computer networks integrated with microcontroller hardware can be utilized for digital data recording and bag identification. The use of a system with a digital method will facilitate the identification of bags. Which will be faster and data stored securely.

The design and manufacture of a web-based travel bag identification system using a microcontroller is a solution for the application of recording data and identification of participant bags from the Umrah or Hajj travel agency. By using this system the travel agency and participants will feel safe and comfortable because the risk of bag swapping is minimal. In addition, all bag and owner data is stored digitally and can be accessed.

\section{Keywords: Arduino Uno, PHP, XAMMP, MYSQL, RFID Scan, Travel Bag}

\section{Pendahuluan}

\subsection{Latar Belakang}

Perkembangan ilmu pengetahuan dan teknologi semakin pesat dari masa ke masa. Salah satunya yaitu di bidang pemrosesan digital dan komputer. Perkembangan dalam dunia pemrosesan data digital dan komputer dapat dimanfaatkan di segala bidang kehidupan. Manfaat yang dimaksud adalah untuk meningkatkan kualitas kehidupan manusia.

Dalam dunia bisnis akses informasi dibutuhkan secara cepat, tepat dan akurat. Perkembangan teknologi dan sistem komputer kini dimanfaatkan untuk memenuhi kebutuhan tersebut. Tak heran, jika saat ini banyak perusahaan dan instansi yang melakukan investasi infrastuktur sistem 
terkomputerisasi dengan nilai yang tidak sedikit. Perusahaan menerapkan sistem tersebut untuk menata dan mengelola informasi secara profesional dan terstandar. Jika di dalam suatu perusahaan, informasi tersebut terhenti atau terhambat, maka sistem perusahaan akan menjadi lusuh (Jogiyanto, 1999). Salah satu data dan informasi yang dikelola oleh instansi dan perusahaan adalah data identifikasi tas pada perusahaan travel. Data ini diperlukan untuk mempermudah proses pemeriksaan, penitipan tas dan identifikasi pemilik. Namun, masih banyak perusahaan Travel yang masih menggunakan metode klasik dalam melakukan sistem pencatatan data pemeriksaan dan identifikasi pemilik. Metode yang digunakan masih menggunakan catatan kertas dan mesin manual. Metode ini memiliki resiko yang besar dalam keamanan data dan pengelolaannya. Resiko tersebut meliputi data tercecer, data rusak, proses kelola data yang lama dan akses pencarian data yang tidak bisa dilakukan secara cepat. Untuk itu, penulis mengambil judul penelitian Rancang bangun Sistem Identifikasi Travel Bag Berbasis Web menggunakan Mikrokontroler sebagai solusi dari semua permasalahan yang telah dikemukakan sebelumnya.

\subsection{Identifikasi Masalah}

Masalah yang ditemukan adalah :

1. Proses pengelolaan data kepemilikan tas masih menggunakan metode cetak manual, sehingga proses kelola data memerlukan waktu yang lama.

2. Kesulitan dalam mengumpulkan dan melakukan proses analisa data yang telah lampau karena belum menggunakan basis data.

3. Resiko terjadinya data hilang dan rusak karena masih menggunakan media kertas.

\subsection{Tujuan}

Tujuan dari Penelitian ini adalah :

1. Merancang perangkat system yang memiliki kemampuan mencatat data tas dan pemiliknya kemudian memprosesnya secara cepat dan tepat.

2. Mempermudah Membuat sistem yang dapat dipergunakan untuk melakukan analisa data pemilik bag yang tercatat dalam basis data.

3. Membuat perangkat dan sistem yang dapat dipergunakan untuk menyimpan data pemeriksaan dan kepemilikan tas dengan aman.

\subsection{Manfaat}

1. Mempermudah proses dan pencatatan data kepemilikan tas.

2. Mempermudah analisa dan dokumentasi data kepemilikan tas yang dapat dipanggil secara cepat.

3. Mencegah terjadinya keterlambatan proses data dan kerusakan atau kehilangan data kepemilikan tas.

\section{Tinjauan Pustaka}

\subsection{Mikrokontroler}

Menurut Barnet (2003), Mikrokontroler merupakan sebuah processor yang digunakan untuk kepentingan kontrol. Menskipun mempunyai bentuk lebih kecil dari komputer pribadi dan mainframe, mikrokontroler dibangun dengan dengan elemen - elemen yang sama. Mikrokontroler adalah alat yang mengerjekan intruksi - intruksi yang diberikan, artinya bagian utama dari suatu sistem otomatis/terkomputerisasi adalah program didalamnya yang dibuat oleh programmer. Perogram mengintruksikan mikrokrontroler untuk melakukan jalinan yang panjang dari aksi - aksi sedrhana untuk melakukan tugas yang lebih kompleks sesuai keinginan programmer.

Beberapa fitur yang umumnya ada ada dalam mikrokontroler, yaitu:

a. RAM (Random Acces Memory)

RAM digunakan oleh mikrokontroler untuk tempat penyimpanan variabe,. Memory ini bersifat volatile yagn berarti akan kehilangan semua datanya jika tidak mendapatkan catu daya.

b. ROM (Read Only Memory)

ROM seringkali juga disebut sebagai code memory karena berfuingsi untuk tempat penyimpanan program yang diberikan oleh programmer. 
c. Register

Register adalah tempat penyimpanan nilai - nilai yang akan digunakan dalam proses, telah disediakan oleh mikrokontroler.

d. SFR (Special function Register)

SFR adalah register khusus yang berfungsi mengatur jalannya mikrokontroler. SFR ini terletak pada RAM.

e. Input dan Output Pin

Pin Input berfungsi sebagai penerima sinyal dari luar (dama seperti Keyboard dalam komputer), pin ini dapat dihubungkan ke media inputan keyboard, sensor, dan sebagainya. Pin output adalah bagian yang berfungksi untku mengeluarkan sinyal dari hasil proses algoritma mikrokontroler.

f. Interrupt

Interupt bagian dari mikrokontroler yang berfungsi sebagai bagian yang dapat melakukan interupsi, sehungga program utama sedang berjalan, program utama tersebut dapat diinterupsi ( mrlompat ke program Interupt service routine).

Beberapa Interrupt pada umumnya, yaitu:

1. Interrupt external : interupsi ini akan terjadi bila ada inputan dari Pin interrupt

2. Interrupt timer : imterupsi ini akan terjadi pada saat tertentu sesuai waktu yang dibutuhkan.

3. Interrupt Serial : interupsi yang akan terjadi ketika terima data pada saat komunikasi serial.

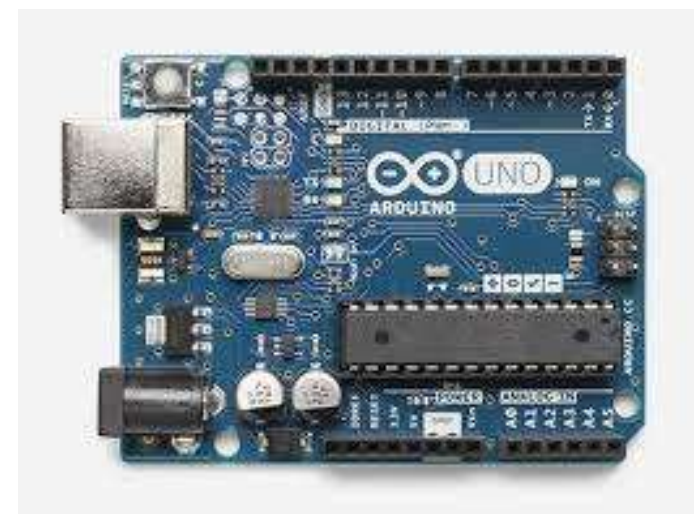

Gambar Mikrokontroler

\subsection{Arduino Uno}

Menurut Sulaiman (2012), arduino merupakan platform yang terdiri dari software dan hardware. Hardware Arduino sama dengan mikrocontroller pada umumnya hanya pada arduino ditambahkan penamaan pin agar mudah diingat. Software Arduino merupakan software open source sehingga dapat di download secara gratis. Software ini digunakan untuk membuat dan memasukkan program ke dalam Arduino. Pemrograman Arduino tidak sebanyak tahapan mikrocontroller konvensional karena Arduino sudah didesain mudah untuk dipelajari, sehingga para pemula dapat mulai belajar mikrocontroller dengan Arduino.

Menurut Santosa (2012), arduino adalah kit elektronik atau papan rangkaian elektronik open source yang di dalamnya terdapat komponen utama yaitu sebuah chip mikrokontroler dengan jenis AVR dari perusahaan Atmel.

Berdasarkan dua definisi yang dikemukakan diatas dapat disimpulkan bahwa arduino merupakan kit elektronik atau papan rangkaian elektronik yang didalamnya terdapat komponen utama yaitu sebuah chip mikrokontroler dengan jenis AVR dari perusahaan Atmel serta sofware pemrograman yang berlisensi open source. 


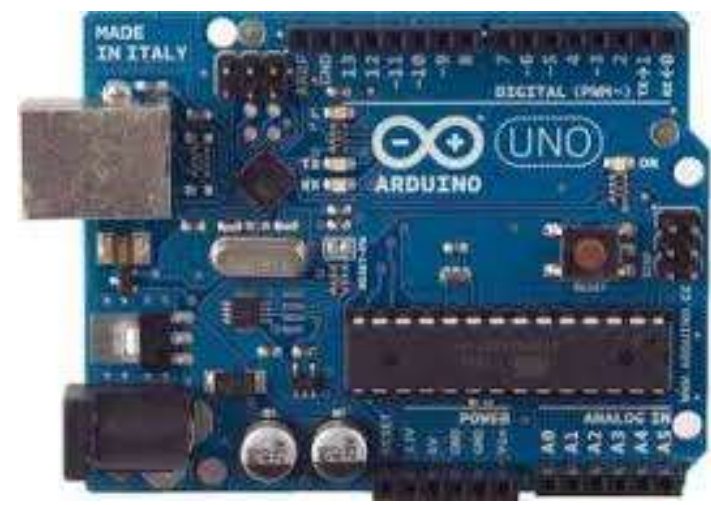

Gambar Arduino Uno

\subsection{Pengertian Web}

Menurut Asropudin (2013), Web adalah sebuah kumpulan halaman yang diawali dengan halaman muka yang berisikan informasi, iklan, serta program aplikasi. Menurut Ardhana (2012), Web adalah suatu layanan sajian informasi yang menggunakan konsep hyperlink, yang memudahkan surfer (sebutan para pemakai komputer yang melakukan browsing atau penelusuran informasi melalui internet). Dari pengertian diatas penulis menyimpulkan Web adalah suatu layanan atau kumpulan halaman yang berisi informasi, iklan, serta program aplikasi yang dapat digunakan oleh surfer.

\subsection{Xammp}

XAMPP adalah perangkat lunak (free software) bebas, yang mendukung untuk banyak sistem operasi, yang merupakan kompilasi dari beberapa program.

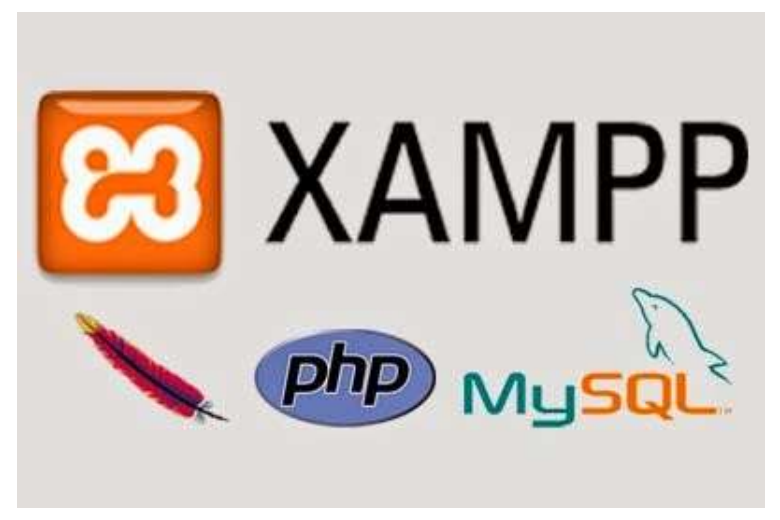

Gambar XAMPP

Fungsi XAMPP sendiri adalah sebagai server yang berdiri sendiri (localhost), yang terdiri beberapa program antara lain : Apache HTTP Server, MySQL database, dan penerjemah bahasa yang ditulis dengan bahasa pemrograman PHP dan Perl. Nama XAMPP sendiri merupakan singkatan dari X (empat sistem operasi apapun), Apache, MySQL, PHP dan Perl. Program ini tersedia dalam GNU General Public License dan bebas, merupakan web server yang mudah untuk digunakan yang dapat menampilkan halaman web yang dinamis. Untuk mendapatkanya XAMPP anda dapat mendownload langsung dari web resminya. Dan berikut beberapa definisi program lainnya yang terdapat dalam XAMPP.

Server HTTP Apache atau Server Web/WWW Apache adalah server web yang dapat dijalankan di banyak sistem operasi seperti (Unix, BSD, Linux, Microsoft Windows dan Novell Netware serta platform lainnya) yang berguna untuk melayani dan memfungsikan situs web. Protokol yang digunakan untuk melayani fasilitas web/www ini menggunakan HTTP. 
MySQL adalah sebuah perangkat lunak sistem manajemen basis data SQL (bahasa Inggris: database management system) atau DBMS yang multithread, multi-user, dengan sekitar 6 juta instalasi di seluruh dunia. MySQL AB membuat MySQL tersedia sebagai perangkat lunak gratis dibawah lisensi GNU General Public License (GPL), tetapi mereka juga menjual dibawah lisensi komersial untuk kasus-kasus dimana penggunaannya tidak cocok dengan penggunaan GPL.

\section{Analisa dan Perancangan}

Dalam sistem ini perangkat yang digunakan dapat dikelompokkan ke dalam dua bagian, yaitu bagian server dan bagian client.

Bagian server terdiri dari dua perangkat utama yaitu komputer server dan perangkat Mikrokontroler dengan komponen pendukungnya. Perangkat komputer server berfungsi untuk menyimpan program web server dan basis data. Program web server yang digunakan adalah XAMPP dengan basis data MySQL. Konektivitas komputer server dengan mikrokontroler Arduino menggunakan Universal Serial Bus (USB), sedangkan konektivitas komputer server dengan perangkat klien menggunakan jaringan komputer lokal nirkabel. untuk itu penulis menggunakan sebuah router wifi untuk menghubungkan kedua perangkat tersebut. Mikrokontroler Arduino dilengkapi dengan modul MFRC522, yaitu modul pemancar dan penerima frekuensi radio yang digunakan untuk mendeteksi kode pada kartu tag.

Pada bagian client, pengguna menggunakan perangkat komputer atau smartphone Android untuk berinteraksi dengan sistem. Pengguna klien adalah administrator untuk mengelola data identifikasi travel bag dan data scan.

Petugas melakukan proses scan dengan cara mendekatkan kartu identifikasi pada perangkat MFRC522. Dari hasil pemindaian tersebut, mikrokontroler mengambil barisan kode unik yang terdapat pada kartu. Barisan kode tersebut kemudian dikirim melalui sambungan serial kepada komputer server. Program pada komputer server menyimpan data kode ke dalam basis data sebagai data travel bag.

\subsection{Analisis Kebutuhan Perangkat Keras}

Berdasarkan pada studi literatur yang telah dilakukan, penulis menentukan beberapa komponen perangkat keras yang diperlukan untuk melakukan rancang bangun sistem. Perangkat yang dimaksud adalah sebagai berikut:

- Mikrokontroler Arduino Uno R3, sebagai pusat pengolah proses instruksi untuk mengirim sinyal logika pada modul relay.

- $\quad$ Modul MFRC522 sebagai pemindai kode unik pada kartu RFID.

- Buzzer pasif, sebagai penanda atau indikator suatu proses.

- $\quad$ Power supply 5 volt, sebagai sumber daya mikrokontroler.

- LCD Karakter 16x2 dengan antarmuka I2C

- Router wifi, sebagai penyedia layanan jaringan komputer lokal nirkabel. Penulis menggunakan router wifi TP LINK TDW-8968

\subsection{Analisis Kebutuhan Perangkat Lunak}

Penulis telah melakukan analisa terhadap kebutuhan perangkat lunak yang diperlukan untuk melakukan rancang bangun sistem. Perangkat lunak yang dibutuhkan adalah sebagai berikut:

- Aplikasi Web Server Apache termasuk di dalamnya program PHP dan basisdata MySQL. Penulis memilih program XAMPP

- Program editor naskah kode pemrograman web, penulis menggunakan program Editplus

- Program IDE (Integrated Development Environment) Arduino, aplikasi ini digunakan untuk membuat pemrograman pada mikrokontroler.

- Library pustaka MFRC522, pustaka tambahan untuk fungsi pemindaian.

- $\quad$ Library pustaka LCD I2C (Inter Integrated Circuit).

- Aplikasi pembuat program Android APK, penulis menggunakan aplikasi online MIT APP Inventory.

- Aplikasi Visual Basic 2010, untuk menyimpan data serial ke dalam basis data secara realtime. 
3.3. Diagram Alir (Flowchart) Algoritma pemrograman Mikrokontroler Berikut ini adalah diagram alir algoritma pemrograman pada mikrokontroler

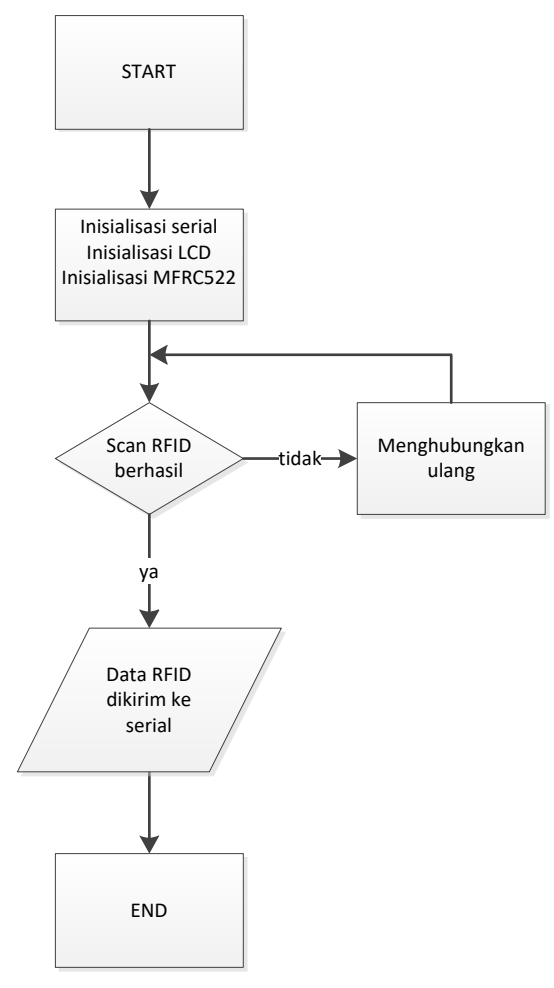

Ketika sistem dijalankan, proses pertama kali yang dilakukan adalah sistem melakukan inisialisasi dan aktifasi terhadap modul-modul yang dibutuhkan. Modul-modul tersebut adalah modul komunikasi serial, modul LCD dan modul RFID. Setelah proses inisialisasi berhasil, selanjutnya sistem masuk ke dalam moda siaga. Moda siaga tersebut adalah tahap menunggu terhadap proses scanning kartu RFID. Ketika terjadi proses scanning data kartu, jika proses scan gagal maka proses akan kembali ke inisialisasi dan pengaktifan modul RFID, namun jika berhasil maka data scan akan dikirim kepada komunikasi serial untuk disimpan ke dalam basis data.

\subsection{ERD (Entity Relationship Diagram)}

ERD adalah diagram relasi antar entitas. Pembuatan diagram ini akan menjadi acuan bagi penulis dalam pembuatan tabel basis data MySQL. Diagram relasi antar entitas yang dimaksud, ditunjukkan oleh gambar

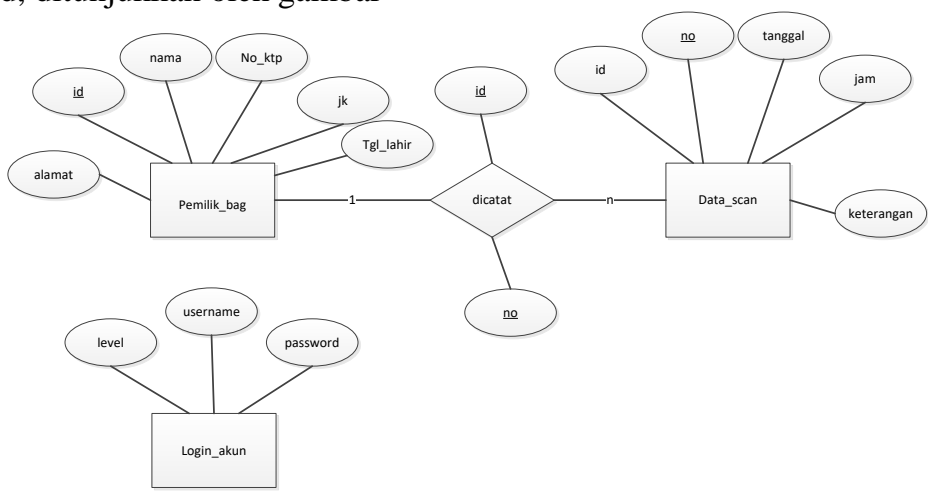

Gambar ERD (Entity Relationship Diagram) 


\subsection{Diagram Konteks}

Diagram konteks merupakan gambaran umum pelaku atau objek yang berinterkasi dengan sistem. Pada sistem ini, penulis menentukan ada tiga objek pengguna dan satu objek perangkat mikrokontroler.

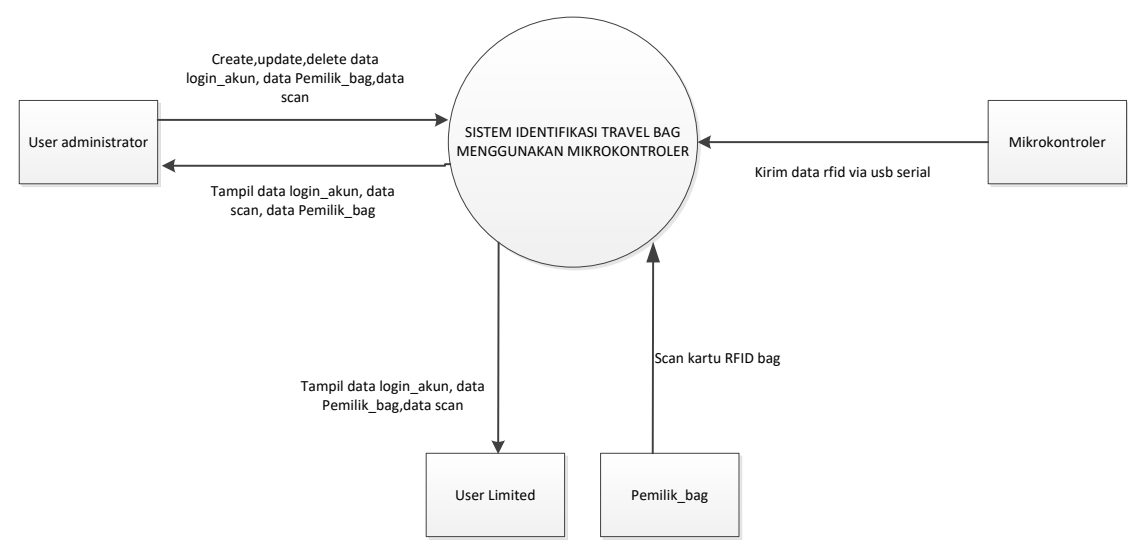

Gambar Diagram Konteks

Pada sistem ini, penulis menentukan ada empat entitas yang berinteraksi dengan sistem. Tiga objek pengguna dan satu objek perangkat mikrokontroler Arduino Uno. Objek pengguna dengan nama entitas user administrator adalah entitas pengguna dengan hak akses penuh. Hak akses penuh yang dimaksud adalah:

1. Melakukan tambah, edit, hapus data pemilik bag, data akun login dan data scan.

2. Melihat data login akun, data pemilik bag dan data scan.

Sedangkan entitas pengguna user limited adalah pengguna yang memiliki hak akses terbatas. Keterbatasan yang dimaksud adalah tidak bisa melakukan modifikasi terhadap data. Tetapi hanya sebatas melihat data scan saja. Entitas pemilik bag hanya melakukan proses scanning kartu rfid sebagai data scan.

\subsection{Data Flow Diagram}

Penulis membuat Data Flow Diagram untuk menguraikan proses dari awal sampai akhir berjalannya sistem. Data Flow Diagram yang dimaksud digambarkan seperti pada Gambar

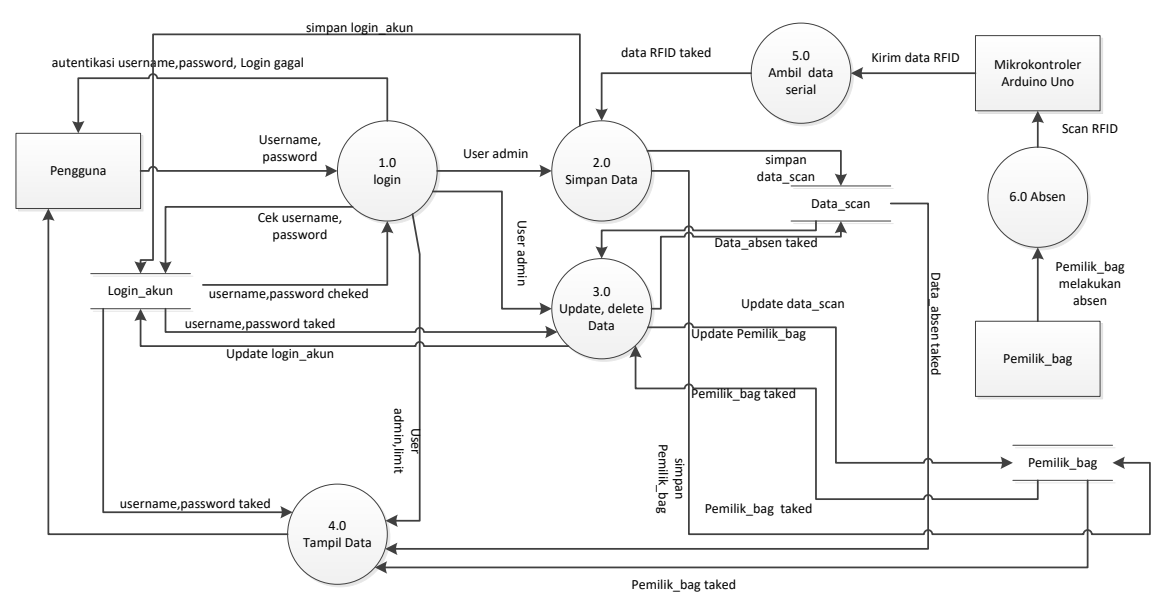

Gambar Data Flow Diagram (DFD) 
Data Flow Diagram atau Diagram alir menunjukkan keseluruhan proses yang terjadi pada sistem. Penulis menentukan ada enam proses utama yang terjadi di dalam sistem, yaitu:

1. Proses 1.0 login, adalah proses awal interaksi pengguna dengan sistem. Pada proses ini terdapat verifikasi data login akun yang akan menentukan keabsahan pengguna dan hak akses yang telah ditentukan.

2. Proses 2.0 Simpan data, proses ini berfungsi untuk menyimpan data pemilik_bag, login_akun dan data_scan.

3. Proses 3.0 Update dan delete data, proses ini merupakan proses modifikasi data. Level akses untuk proses ini hanya diizinkan bagi pengguna administrator.

4. Proses 4.0 Tampil data, proses ini menampilkan seluruh data sesuai dengan kebutuhan sistem.

5. Proses 5.0 Ambil data serial, proses ini berfungsi untuk mengambil data dari komunikasi serial. Data dari mikrokontroler diteruskan ke proses simpan data melalui proses 5.0 ambil data serial ini.

6. Proses 6.0 Absen, proses ini adalah proses inputan dimana pemilik_bag melalukan scanning kartu RFID yang datanya kemudian diproses oleh mikrokontroler untuk diteruskan kepada komunikasi serial.

\subsection{Struktur tabel}

3.7.1 Struktur tabel login_akun

Tabel Struktur tabel login_akun

\begin{tabular}{|l|l|r|l|}
\hline Nama Field & \multicolumn{1}{|c|}{ Type data } & \multicolumn{1}{|c|}{ Size } & Description \\
\hline level & varchar & 50 & \\
\hline username & varchar & 50 & PK \\
\hline password & varchar & 50 & \\
\hline
\end{tabular}

3.7.2 Struktur tabel pemilik_bag

Tabel Struktur tabel pemilik_bag

\begin{tabular}{|l|l|r|l|}
\hline Nama Field & Tipe & Size & Description \\
\hline id & varchar & 50 & PK \\
\hline nama & varchar & 50 & \\
\hline No_ktp & varchar & 50 & \\
\hline jk & varchar & 2 & \\
\hline tgl_lahir & Date & & \\
\hline alamat & varchar & 500 & \\
\hline
\end{tabular}

\subsubsection{Struktur tabel data scan}

Tabel Struktur tabel data_scan

\begin{tabular}{|l|l|r|l|}
\hline Nama Field & Tipe & Size & Description \\
\hline no & INT & 255 & PK \\
\hline id & varchar & 50 & FK \\
\hline tanggal & Date & & \\
\hline jam & Time & & \\
\hline keterangan & varchar & 50 & \\
\hline
\end{tabular}

\subsection{Perancangan Antarmuka}

Penulis membagi layout tampilan perancangan antarmuka sistem dengan pengguna menjadi beberapa bagian. Pembuatan desain ini untuk mempermudah interaksi pengguna, sebagai identitas sistem dan juga untuk memperindah penampilan sistem. Perancangan antarmuka sistem yang dimaksud ditunjukkan seperti pada gambar 


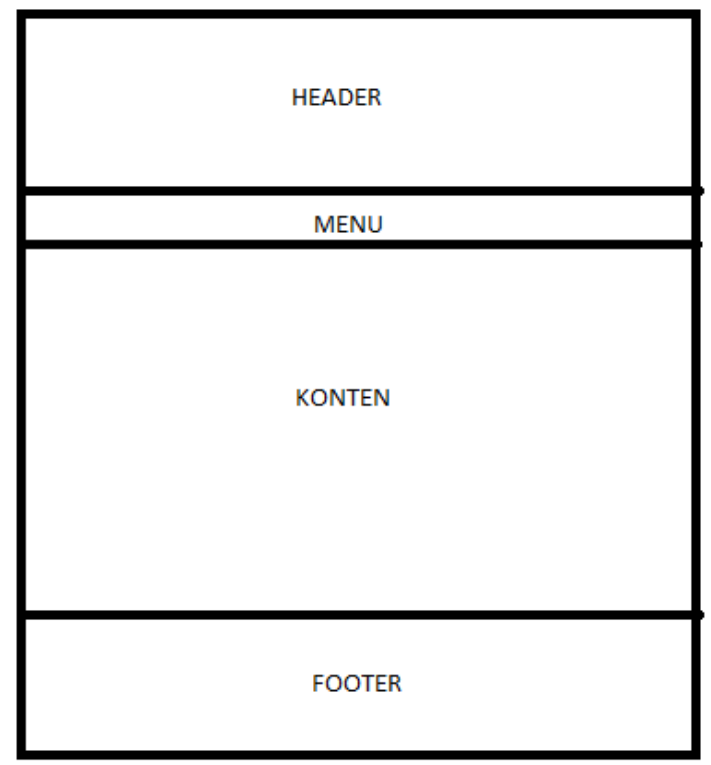

Gambar Perancangan Antarmuka

Penjelasan mengenai bagian-bagian perancangan antarmuka adalah sebagai berikut:

1. Header, adalah bagian dari identitas sistem. Header berisi gambar yang berkaitan dengan tema atau konten sistem.

2. Menu, adalah navigasi sistem yang terkoneksi dengan modul-modul tertentu dalam sistem.

3. Konten, adalah isi utama penyajian data atau interaksi sistem dengan pengguna.

4. Footer, adalah catatan identitas sistem.

\subsection{Arsitektur Sistem Jaringan}

Penulis melakukan perancangan jaringan komputer lokal secara nirkabel sebagai jalur berjalannya sistem. Perancangan tersebut diperlihatkan seperti pada gambar.

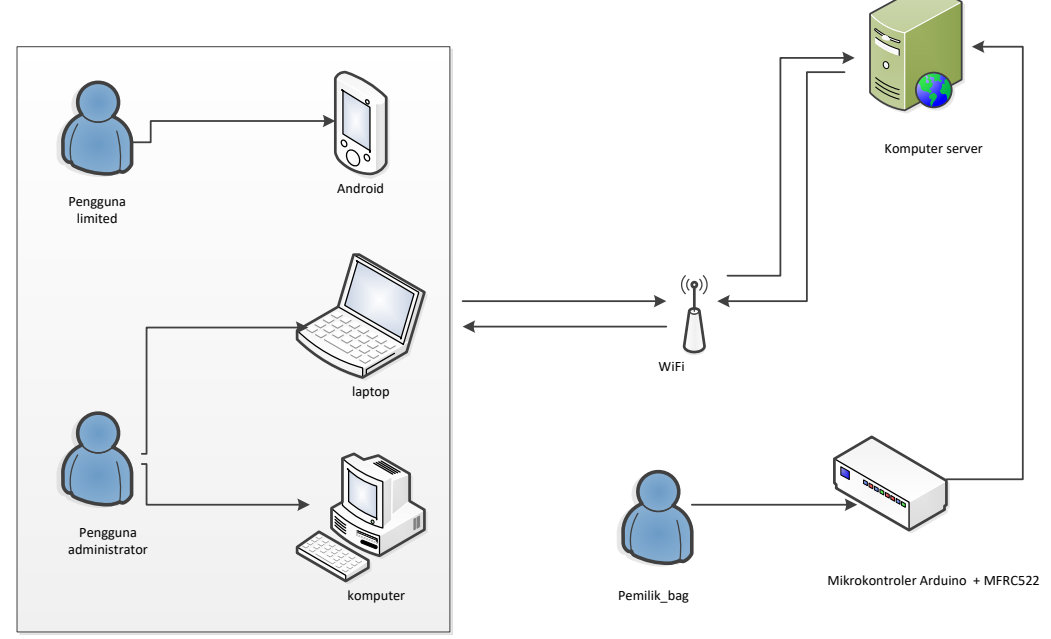

Gamba Perancangan Arsitektur Sistem Jaringan

Pada gambar di atas, terlihat bahwa berjalannya sistem adalah melalui media jaringan komputer lokal nirkabel. Pengguna dapat melakukan sambungan ke dalam sistem 
menggunakan perangkat komputer laptop, komputer desktop atau smartphoneAndroid. Komputer server dan perangkat mikrokontroler pun harus tersambung ke dalam jaringan yang sama dengan pengguna.

Setelah menentukan topologi perancangan jaringan komputer, penulis menentukan pengalamatan IP Address perangkat server dan klien atau pengguna. Pengalamatan alamat IP Address tersebut diperlihatkan pada tabel

Tabel Penentuan Alamat IP Address Perangkat uji

\begin{tabular}{|r|l|l|l|l|}
\hline \multicolumn{1}{|c|}{ NO } & \multicolumn{1}{|c|}{ NAMA PERANGKAT } & \multicolumn{1}{c|}{ IP ADDRESS } & \multicolumn{1}{c|}{$\begin{array}{c}\text { MUNET } \\
\text { MASK }\end{array}$} & GATEWAY \\
\hline 1 & TP-LINK TDW8968 & 192.168 .1 .1 & 255.255 .255 .0 & 192.168 .1 .1 \\
\hline 2 & KOMPUTER SERVER & 192.168 .1 .105 & 255.255 .255 .0 & 192.168 .1 .1 \\
\hline 3 & KOMPUTER KLIEN & 192.168 .1 .101 & 255.255 .255 .0 & 192.168 .1 .1 \\
\hline 4 & SMARTPHONE KLIEN & 192.168 .1 .102 & 255.255 .255 .0 & 192.168 .1 .1 \\
\hline
\end{tabular}

\section{Hasil}

4.1. Implementasi pembangunan sistem web server

Sistem yang penulis rancang secara teknis memiliki basis antarmuka web. Untuk mendukung hal ini, diperlukan program yang memiliki kemampuan sebagai sebagai penyedia layanan web. Penulis memilih program XAMPP dengan Apache Web Server. Program XAMPP selain memiliki kemampuan sebagai penyedia layanan web, juga memiliki basis data terintegrasi yaitu MySQL. Basis data diperlukan untuk menyimpan data-data dari proses aktifitas pengguna pada sistem.

Proses instalasi web server XAMPP begitu mudah. Penulis hanya tinggal mengeksekusi file setup XAMPP, dan proses instalasi pun berjalan. Proses instalasi seperti yang dimaksud, adalah sebagai berikut,

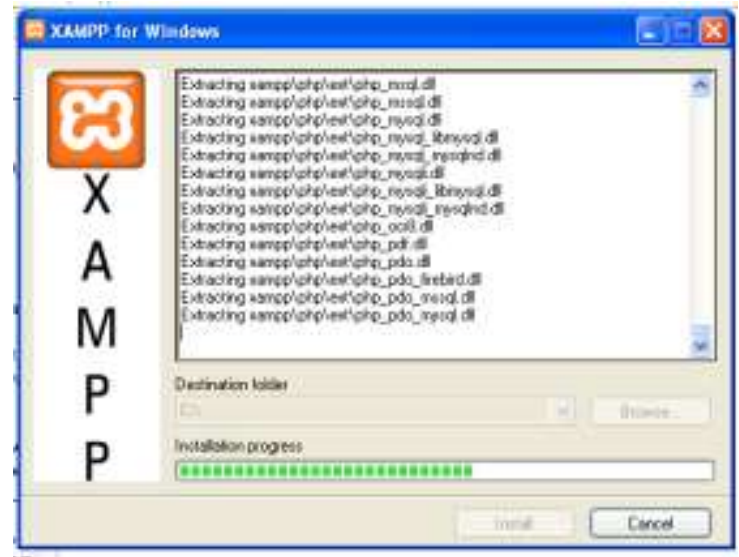

Gambar Proses Instalasi program XAMPP for Windows

Setelah selesai proses instalasi, penulis melakukan pengujian terhadap layanan web server. Penulis memasukkan alamat web dengan mengetikkan teks "localhost", maka muncul halaman web XAMPP yang menandakan bahwa layanan web server telah bekerja. Halaman web XAMPP yang dimaksud adalah sebagaimana ditunjukkan pada gambar 


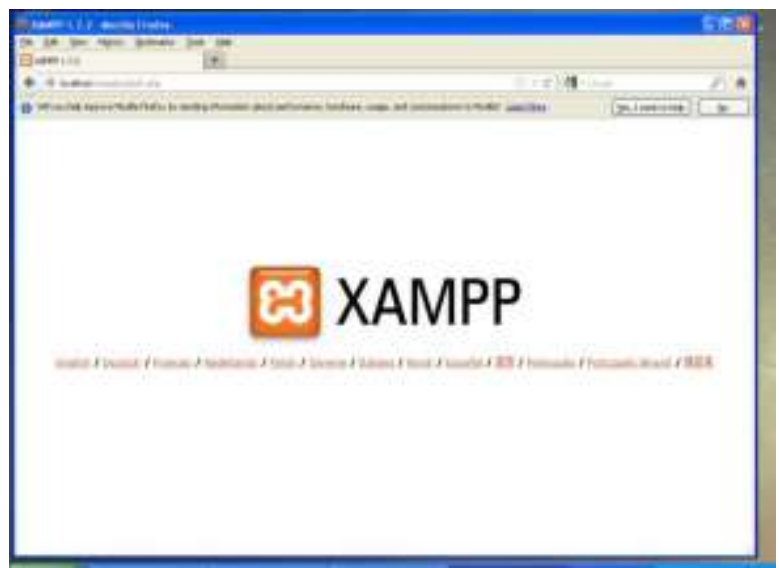

\subsection{Implementasi pembuatan basis data MySQL}

Gambar Program XAMPP berhasil diinstal

Keberadaan basis data pada perancangan sistem ini sangat penting. Penulis menetapkan basis data untuk menyimpan data akun login pengguna, data karyawan dan data. Tabel data karyawan terelasi dengan tabel data absensi berdasarkan nomor identitas.

Berdasarkan pembuatan struktur tabel yang telah penulis lakukan, maka penulis melakukan perancangan basis data disertai relasi sebagaimana ditunjukkan oleh gambar sebagai berikut,

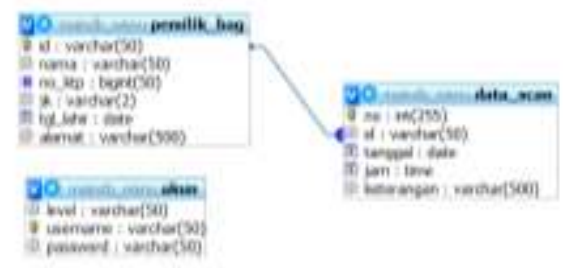

Gambar Relasi Tabel dalam Basis Data

\subsection{Implementasi perancangan antarmuka web}

Penulis menggunakan program Notepad++ untuk melakukan suntingan naskah kode pemrograman web. Proses penyuntingan naskah yang dimaksud, sebagaimana ditunjukkan pada gambar sebagai berikut,

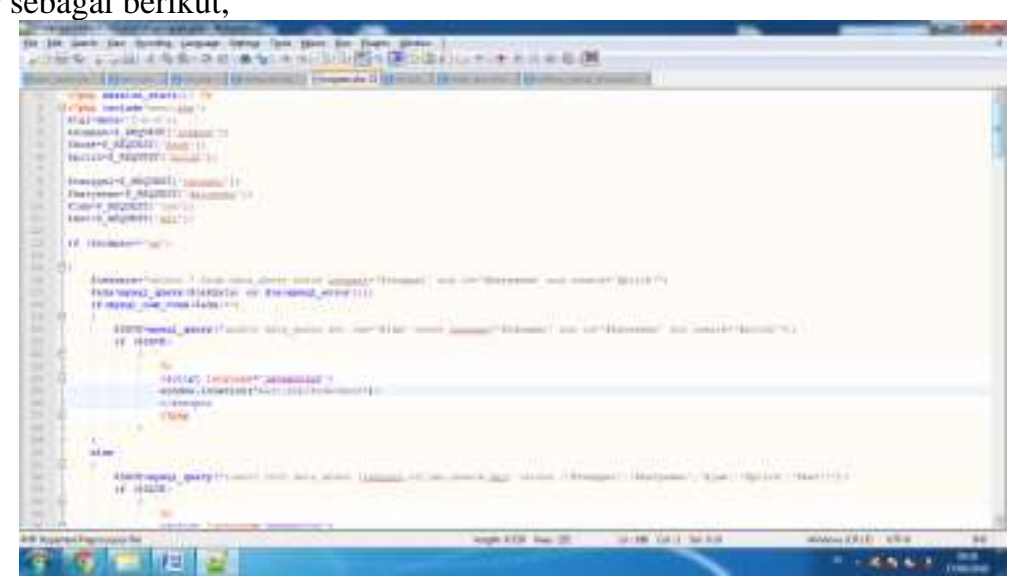

Gambar Pembuatan Naskah Program Web

a. Implementasi perancangan antarmuka halaman login

Halaman login diperlukan untuk menentukan kategori pengguna yang masuk ke dalam sistem. Penulis menentukan ada dua jenis kategori pengguna yang berbeda berdasarkan level. Pertama adalah pengguna level administrator yang memiliki hak akses penuh untuk melihat, menambah, 
mengubah dan menghapus semua data. Sedangkan yang kedua adalah penggguna level limited. Pengguna level ini hanya diberikan hak akses untuk melihat data saja. Proses pembuataan halaman login yang dimaksud, ditunjukkan pada gambar a.implementasi perancangan anatrmuka tampilan login

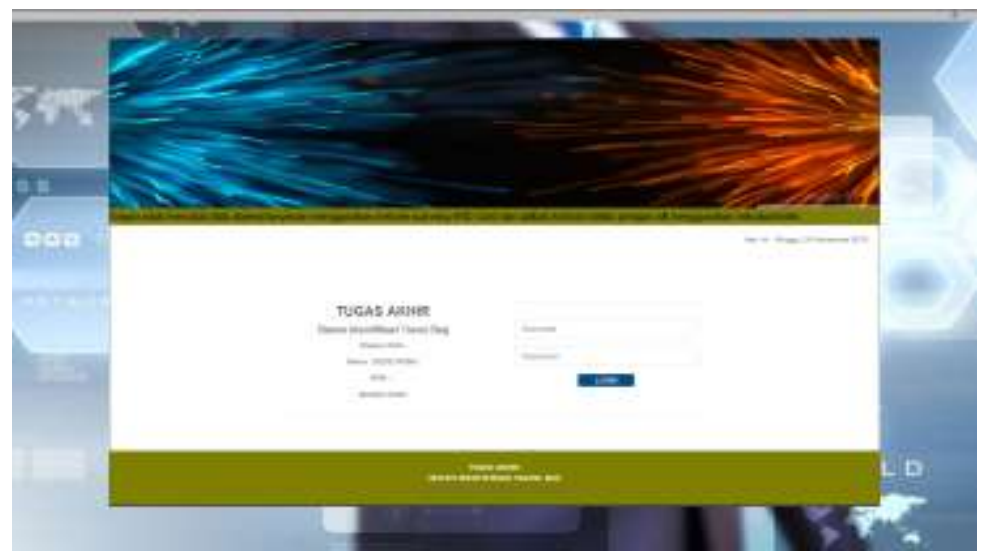

Gambar Implementasi perancangan antarmuka halaman login

b. Implementasi perancangan antarmuka tampilan data scan

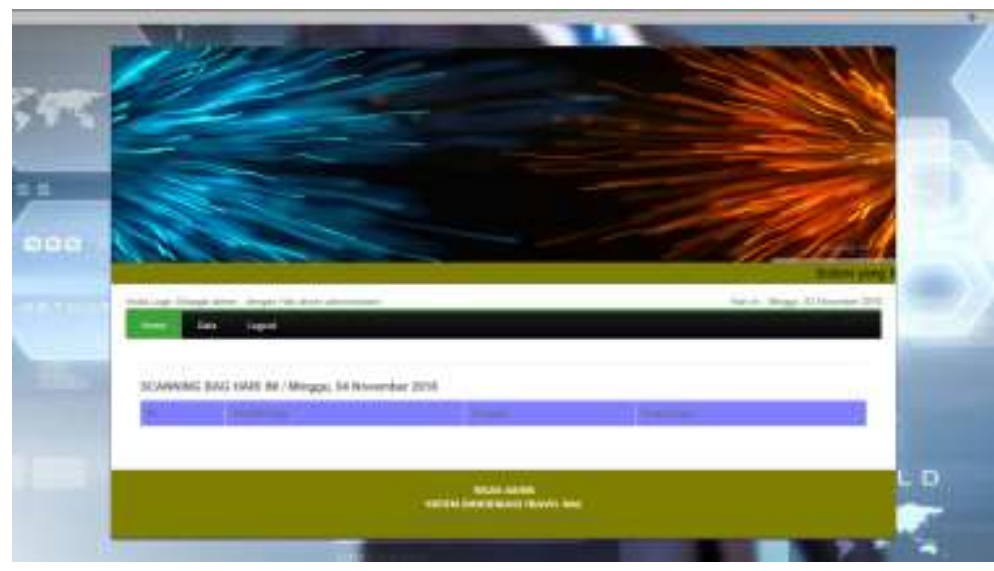

Gambar Implementasi perancangan antarmuka data scan

\subsection{Implementasi Pemrograman Mikrokontroler}

Pemrograman pada mikrokontroler menggunakan bahasa C. Penulis menggunakan program IDE (Integrated Development Environment) Arduino versi 1.8.2. Program ini dapat mengidentifikasi validitas barisan naskah program, melakukan proses compile atau menerjemahkan barisan program ke dalam bahasa biner, dan mampu menuliskan hasil compile ke dalam mikrokontroler. File project dari program Arduino memiliki extensi file ino.

Berdasarkan flowchart algoritma pemrograman yang telah dibuat, penulis melakukan penulisan naskah pemrograman dengan inisialisasi awal mengaktifkan fungsi komunikasi data serial dan fungsi LCD. Kemudian pemrogaman MFRC522 dibuat untuk mengambil data kode unik yang terdapat pada kartu RFID. Kode unik yang telah diidentifikasi kemudian dikirim kepada komunikasi serial untuk diproses lebih lanjut oleh program pada komputer server.

Setelah selesai melakukan penulisan naskah program, penulis melakukan proses upload untuk memasukkan program ke dalam mikrokontroler. Proses memasukkan program ke dalam mikrokontroler yang dimaksud, ditunjukkan oleh gambar 


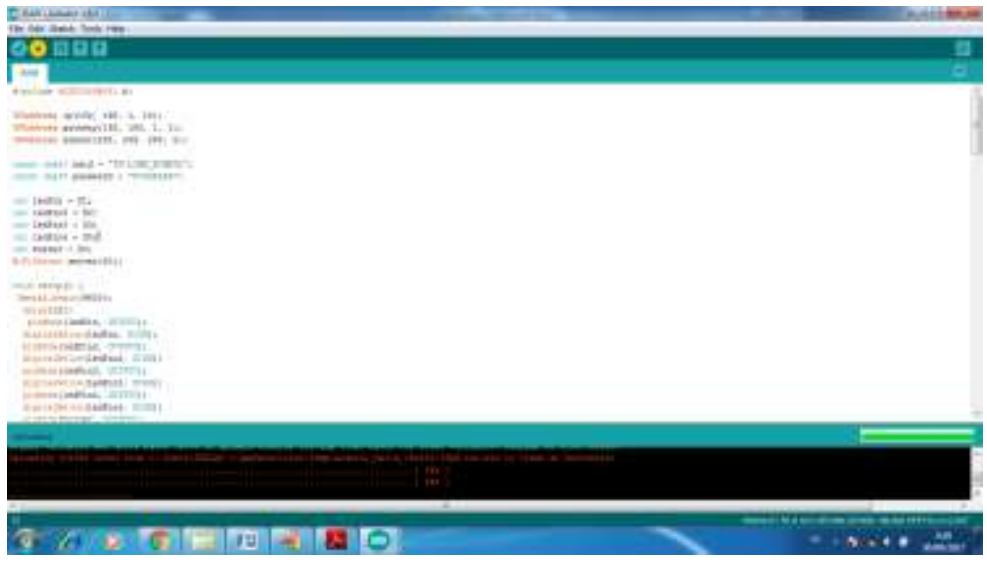

\subsection{Implementasi Pemrograman Visual Basic 2010}

Pemrograman dengan program visual basic bertujuan untuk membuat program yang berfungsi menyimpan data serial secara realtime. Data serial berasal dari kode unik kartu RFID yang dikirim oleh mikrokontroler kepada komunikasi serial. Data tersebut akan dijadikan kode identitas pemilik_bag untuk melakukan scan.

Penulis melakukan instalasi program visual basic 2010. Instalasi program yang dimaksud, ditunjukkan pada gambar

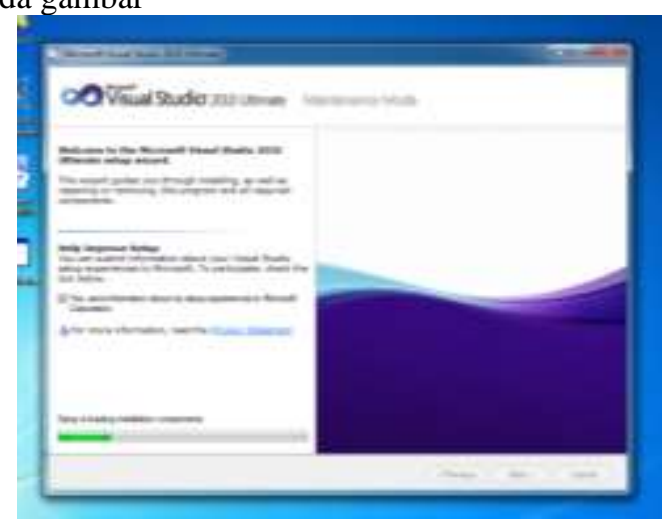

Setelah program Visual Basic Studio 2010 berhasil diinstal, selanjutnya penulis membuat project baru. Pembuatan project baru tersebut ditunjukkan pada gambar

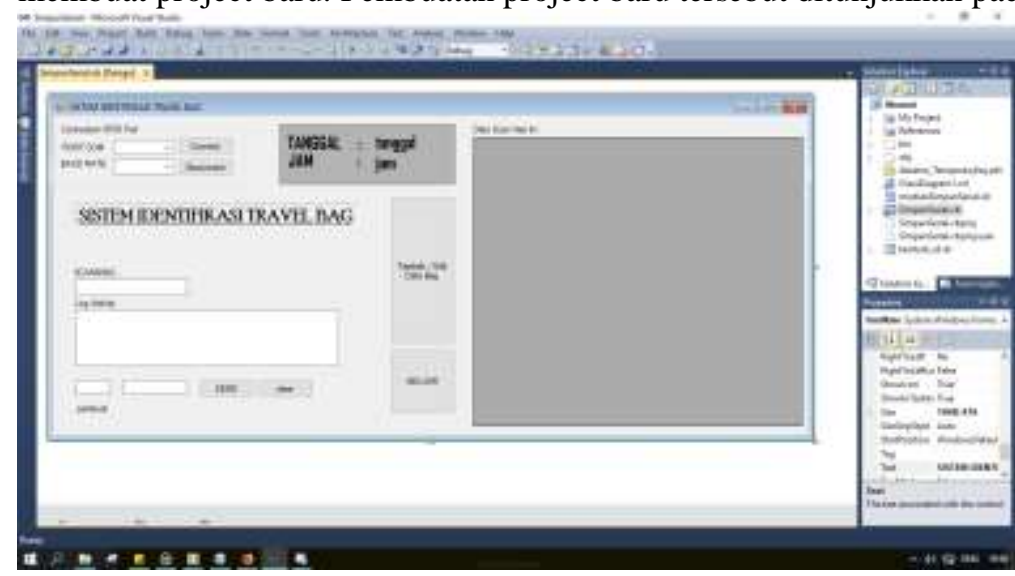

Pemrograman pada Visual Studio meliputi:

- Pemrograman koneksi komunikasi serial

- Pemrograman timer interval fungsi untuk menyimpan data 


\section{- Pemrograman koneksi basis data MySql \\ - Pemrograman CRUD (Create Read Update Delete) tabel basis data.}

\subsection{Pengujian dengan akses program browser}

Pengujian dengan menggunakan media program web dilakukan untuk menampilkan laporan isi basis data berdasarkan parameter tertentu. Setelah semua perangkat terhubung dengan baik, menggunakan perangkat smartphone, penulis melakukan akses halaman web komputer server dengan alamat 192.168.1.100. Kemudian penulis melakukan login ke dalam sistem. Setelah itu, penulis melakukan pengujian akses pada setiap tautan antarmuka sistem. Penulis juga melakukan pencarian data absensi berdasarkan tanggal dan nama karyawan. Pengujian melalui program browser yang dimaksud, ditunjukkan oleh gambar

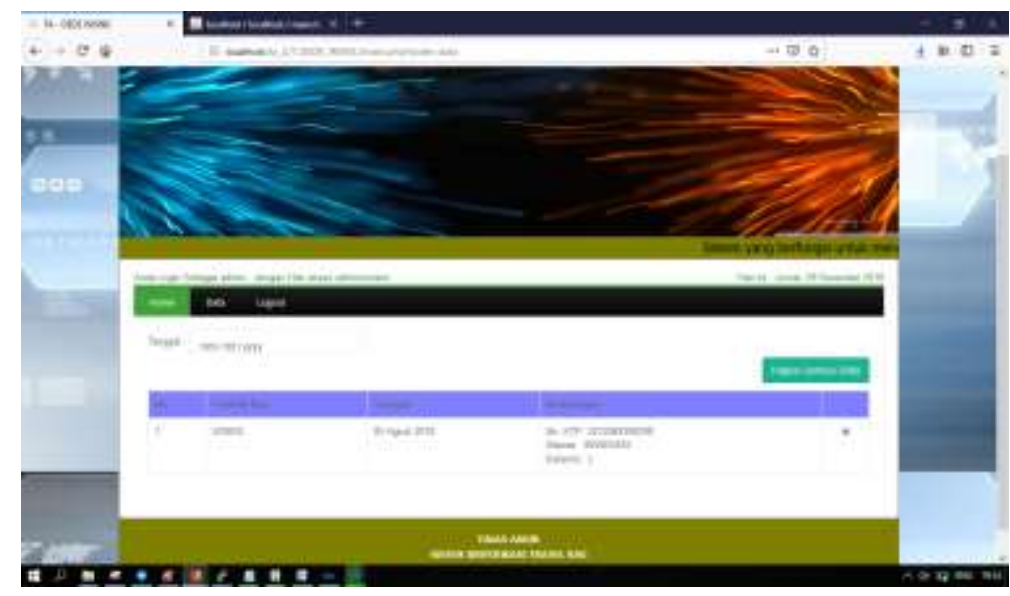

\section{Kesimpulan}

Dari hasil pembahasan mengenai Rancang sistem pengidentifikasi travel bag pada kelompok biro perjalanan umroh/haji berbasis web Otomatis Menggunakan Mikrokontroler Esp8266 yaitu:

1. Pencatatan yang dilakukan secara otomatis dan tidak menyulitkan proses identifikasi tas pada peserta umrah.

2. Sistem pengidentifikasi travel bag pada kelompok biro perjalanan umroh/haji berbasis web Otomatis dapat tercapai menggunakan Arduino Uno, PHP, XAMMP, MYSQL, RFID Scan

\section{Daftar Pustaka}

[1] R.A.Ramlee, M.H.Leong, R.S.S.Singh, M.M.Ismail, M.A.Othman, H.A.Sulaiman, M.H.Misran, M.A.Meor Said, "Bluetooth Remote Home Automation System Using Android Application", The International Journal of Engineering And Science (IJES), Volume 2, Issue 01, Pages149-153 ,2013, ISSN: 2319 - 1813 ISBN: 2319 - 1805, 2013.

[2] I. Warangkiran, T.G. Kaunang, A. S. M. Kaunang, A. M. Rumagit, "Perancangan Kendali Lampu Berbasis Android," e-journal Teknik Elektro dan Komputer, Volume 3 No. 1, Hal. $1-8,2014$.

[3] A. Kadir, Pengenalan Sistem Informasi, Yogyakarta: Andi, 2003.

[4] M. B. Romey, and P. J. Steinbart, Accounting Information Systems, 13th ed. England: Pearson Education Limited, 2015.

[5] Gelinas, A. Ulrich, A. Oram \& W. Wringins, Accounting Information Systems. South Western Cengange Learning. 5191 Natorp Boulevard Mason, USA. P. 19, 2012.

[6] R. A. Kusuma, Pengertian sensor pada rangkaian elektronika, 21 Septermber 2015. Diakses pada 3 Oktober 2017. [Online]. Tersedia: http://skemaku.com/pengertian-sensor-padarangkaian-elektronika/ 
[7] A. Sulaiman, ARDUINO: Mikrokontroller bagi Pemula hingga Mahir, Diakses pada: 3 Oktober 2017. [Online]. Tersedia pada: http://buletin.balaielektronika.com/?p=163

[8] S. Santoso, Panduan Lengkap SPSS Versi 20. Jakarta: PT Elex Media Komputindo, 2012.

[9] R. H. Barnett, S.A. Cox, L. D. O'Cull, Embedded C Programming and the Atmel AVR. New York: Thomson Delmar Learning, 2013.

[10] Haviluddin, "Memahami Penggunaan Diagram Arus Data.Jurnal Informatika Mulwarman," Vol. 4 No. 3, September 2009.

[11] Setiawan, Pengertian dan Jenis - jenis absensi, http://www.gurupendidikan.co.id/pengertiandan-jenis-jenis-absensi, 2015

[10] H.M. Jogiyanto, Analisis dan Desain Sistem Informasi: Pendekatan Terstruktur Teori dan Praktek Aplikasi Bisnis. Yogyakarta: Andi Offset, 2005. 